\title{
Water Resource Management Plan of a Micro-Watershed using Geospatial Techniques
}

\author{
Madhukar Patel ${ }^{1 *}$ and Dhiraj Khalkho ${ }^{2}$ \\ ${ }^{1}$ Agricultural Engineering, College of Agriculture \& Research Station, Raigarh, India \\ ${ }^{2}$ Department of Soil and Water Engineering, SVCAET\&RS, FAE, IGKV, Raipur, India \\ *Corresponding author
}

\section{A B S T R A C T}

\section{Keywords}

GIS, Remote sensing, Land use land cover maps, Water resource management

Article Info

Accepted:

04 January 2019

Available Online:

10 February 2019

\begin{abstract}
Geospatial technique were used for land and water management action plan for Dhangaon micro watershed in Bemetara district, Chhattisgarh. Keeping in view the need of micro level planning and usefulness of modern tools and technology a study on water resource planning of water resources for micro watershed was conducted. The objective of the present research work was to prepare the thematic maps of land use/ land cover, soil, slope and drainage using satellite imagery data and survey of India (SOI) toposheet of micro watershed and to integrate all the maps under GIS environment to prepare the water resource management plans for the study of micro watershed. The study will be helpful in identification of sites for construction of different soil and water conservation structures like water harvesting structures, check dams, farm ponds, percolation tanks, nala widening and deepening of drainage network etc. Different soil and water conservation works are suggested under water resource action plan with specific sites, locations and maps. The study will be helpful in sustainable development of the natural resources of the micro watershed with the proper implementation of the proposed action plans.
\end{abstract}

\section{Introduction}

Water resource management planning has regard to all the competing demands for water and seeks to allocate water on an equitable basis to satisfy all uses and demands. Agriculture is the mainstay of the state of Chhattisgarh. Chhattisgarh's economy is predominantly agriculture based. It is the main occupation of the people. Paddy is the principal crop and the central plains of Chhattisgarh are known as rice bowl of central India. To make any developmental programme successful, site specific management plan has to be generated and implemented depending on the needs of the field (Khalkho et al., 2014). Agriculture is the largest user of the world's freshwater resources, consuming $70 \%$. Geospatial technologies such as remote sensing (RS) and Geographic Information System (GIS) have been found to be effective tools for delineating rainwater harvesting potential zones and selecting sites for rainwater harvesting structures, and play a vital role in the planning and management of water 
resources (Jha and Peiffer, 2006). The aim has been to ensure the availability of drinking water, fuel wood, and fodder and raise income and employment for farmers and landless labourers through improvement in agricultural production and productivity (Rao, 2000).

Keeping in view the above said importance of natural resource management plan is to be developed on micro watershed scale. The present study was undertaken with a specific objective of developing site specific waterresources management plan at cadastral/field level for providing management plan to individual farmer.

\section{Materials and Methods}

\section{Study area}

Dhangaon micro-watershed of Bemetara block of Bemetara district and located between $21^{\circ} 49^{\prime} 0$ "'and $21^{\circ} 51^{\prime} 0$ " ' $\mathrm{N}$ latitudes and $81^{\circ} 33^{\prime} 30^{\prime \prime}$ and $81^{\circ} 35^{\prime} 30^{\prime}$ " E longitudes was adopted for the study (Figure 1). It falls in SOI topographical map no. 64G/9 on scale1: 50,000. The study was carried out in the department of soil and water engineering, Faculty of Agril. Engg., Raipur during 20132015. The geographical area of microwatershed was found to be 573.44 ha. The general elevation of the study area ranges from $262 \mathrm{~m}$ to $278 \mathrm{~m}$ above mean sea level (MSL). The annual average rainfall of the area is $1140 \mathrm{~mm}$. The predominant soil of watershed is clay though sandy loam, sandy clay loam, loam and clay loam were also found in the watershed. The watershed receives an average annual rainfall of 1140 $\mathrm{mm}$. The daily mean temperature ranges from $40.0^{\circ} \mathrm{C}$ to $3.0^{\circ} \mathrm{C}$. The daily mean relative humidity varies from a minimum of $40 \%$ in the month of April to a maximum of $88 \%$ in the month of July. The overall climate of the area can be classified as sub-tropical. Dhangaon is situated $10 \mathrm{~km}$ from the district headquarter Bemetara, which is well connected to Jabalpur, Raipur, Bilaspur, Durg and Kawardha by road network. The nearest railway station is Tilda railway station under SECR which is about $40 \mathrm{~km}$ from Dhangaon. The nearest airport is Raipur which is about $77 \mathrm{~km}$ from Dhangaon.

IRS-P6 (LISS-IV) satellite data of $10^{\text {th }}$ October 2014 (path/row: 102/57) was used in this study. Survey of India (SOI) toposheet 64-G/9 of 1:50000 was used to prepare base map of the study area. Various thematic maps like drainage, water bodies were extended from base map, field work and ground truth verification. The cadastral map of the 1:4000 scale was acquired for the Department of Land Revenue, Government of Chhattisgarh, for the field level information of the Dhangaon village. The toposheet and cadastral map is digitized and georectified. The database of field level information from the land records and cadastral map was generated to give the clear picture about the land holdings of the inhabitants. ERDAS IMAGNE 2011 and ArcGIS 10 software were used for image processing and GIS work. Pixel based classification was adopted for the classification of land use/ land cover form the satellite image. Digitized revenue or cadastral map was used to delineate each and every field with the creation of digital database of the land records.

Following resampling, geometrically corrected near-infrared, red and green band of the LISS IV data was used to generate a false color composite (FCC) of the study area. Supervised classification was used to identify the various land cover pattern of the area and delineation of water bodies. Data obtained by ground truthing using GPS (Global Positioning system) were used for pixel based image classification. Various thematic maps were generated like soil texture, land use, land cover, drainage network and DEM. Grid 
based soil sampling was done to get representative of the four farming situations for analyzing the profile of the study area. The soil sampling of the village was analyzed for giving the field condition of Microwatershed in perspective of the farming situation and fertility. Different variety of crops were suggested based on the farming situation, land use and land cover. The methodology adopted for the study is presented in the form of flow chart in Figure 2.

\section{Results and Discussion}

\section{Topography}

The topography of the present micro watershed area is gentle to undulating. Major soil types found in the micro-watershed are; Entisols (Sandy loam) Inceptisols (Sandy clay loam) Alfisol (Loam) Vertisols (Clay). Lands are fertile having moisture retention capacity with monsoonic rain and good vegetation. Agriculture lands in the area are productive but some where it is unproductive due to biotic-interference and soil erosion. Paddy is the dominant agriculture crop along with soybean and pigeon pea in kharif and followed by chickpea, wheat etc.

\section{Drainage Map}

Drainage map comprises of various streams that are flowing in the area. Drainage patterns and textures are dissection signatures and very important terrain recognition elements, used as criteria for identification of geological and geomorphological phenomena. In this pattern, the smallest finger-type tributaries are designated order1; where two first order channels join, a channel segment of order 2 is formed; where two channels of order 2 join, a segment of order 3 is formed and so forth. This happens due to the land slope pattern and also the characteristics of soil. $1^{\text {st }}$ and $2^{\text {nd }}$ order stream were found at Dhangaon microwatershed with $4.14 \mathrm{~km}$ and $3.3 \mathrm{~km}$ length respectively. The total length of the stream found was to be $7.17 \mathrm{~km}$. In Dhangaon micro watershed, Hamp River flows from its Northern boundary which affects mostly the drainage pattern in the micro watershed. The drainage density was found to be 1.28 $\mathrm{km} / \mathrm{km}^{2}$ (Figure 3 ). The low value of drainage density reflects the dominations of over all flow in the study area.

\section{Land use/ land cover}

Based on the pixel based classification and image characteristics eight land use classes (Figure 4) were identified in the watershed with major part of the study area dominated by paddy crop (199.37 ha) which is $33 \%$ of the total area. This is followed by Soybean (124.07 ha), which is $21.54 \%$ current fallow (113.08 ha) which is $19.64 \%$ of the total area pigeon pea (54.439 ha) which is $9.45 \%$ of the total area. Deep water body contributes $2.15 \%$ of the total area and small water body by $0.015 \%$ of the total area.

\section{Soils}

The soil texture of the Dhangaon Microwatershed (Figure 5) varies from sandy loam to clay. Four classes of soil texture were identified with Inceptisols (sandy clay loam) contribute 309.84 ha, which is $60.86 \%$ of the total area followed by Alfisol covering 161.826 ha, along with vertisols and Entisols covering (72.69 ha) and (46.74 ha) respectively. Soil erosion depends much on the infiltration rate of a soil.

The infiltration rate depends on the soil texture as in sandy soil the infiltration rate is higher than silty soil. In a clayey soil it may be initially high (for heavy black clay with cracking), but becomes low when the soil is moist to wet. Soil Health is a state of a soil 
meeting its range of ecosystem function as appropriate to its environment. A soil analysis is a process by which elements such as $\mathrm{P}, \mathrm{K}$, $\mathrm{Ca}, \mathrm{Mg}, \mathrm{Na}, \mathrm{S}, \mathrm{Mn}, \mathrm{Cu}$ and $\mathrm{Zn}$ are chemically extracted from the soil and measured for their "plant available" content within the soil sample.

\section{DEM}

Digital Elevation Model (DEM) was generated (Figure 6) using the contour map along with the field surveys and done using global positioning system (GPS). The elevation of the project area was found to be in the range of 534-661 m above mean sea level. The DEM was generated by the classifying the relief in four class. Viz. 851to
$870 \mathrm{ft}, 871$ to $871-885 \mathrm{ft}, 886$ to $897 \mathrm{ft}$ and 898 to $913 \mathrm{ft}$ respectively.

\section{Water resources development plan}

The water resource development plan of Dhangaon micro watersheds was prepared by overlaying land use/land cover map, slope map, soil map and drainage map using ArcGIS software packages in GIS, respectively. The water resources management plan is generated to make the judicious and effective use of water resources of the micro watershed to enhance the productivity and mitigate drought. The plan indicates sites for surface water development and groundwater exploitation.

Table.1 Water availability in the micro watershed

\begin{tabular}{|l|c|}
\hline & in $\mathbf{M m}^{\mathbf{3}}$ \\
\hline Rainfall volume & 6.50 \\
\hline Runoff volume & 1.63 \\
\hline Crop requirement & 2.70 \\
\hline Released through tank & 0.24 \\
\hline Net ground water available & 1.26 \\
\hline
\end{tabular}

Table. 2 Crop water requirement

\begin{tabular}{|c|c|c|c|c|}
\hline $\begin{array}{l}\text { Farming } \\
\text { Situation }\end{array}$ & $\begin{array}{l}\text { Area under current } \\
\text { fallow (ha) }\end{array}$ & Proposed Crop & $\begin{array}{l}\text { Water requirement } \\
\qquad(\mathrm{mm})\end{array}$ & $\mathrm{Mm}^{3}$ \\
\hline Bhata & 12 & Pigeon Pea & 0.30 & 0.03 \\
\hline Matasi & 60 & Soybean & 0.65 & 0.39 \\
\hline Dorsa & 40 & Paddy & 0.90 & 0.36 \\
\hline Total & 112 & & 1.85 & 0.78 \\
\hline
\end{tabular}

Table.3 Proposed structures for water harvesting in the micro watershed

\begin{tabular}{|c|l|c|}
\hline SI. No. & Type of Structures & Quantity \\
\hline 1. & Check Dam & 3 \\
\hline 2. & Farm Pond & 3 \\
\hline 3. & Percolation Tank & 3 \\
\hline
\end{tabular}


Fig.1 Location of the study area

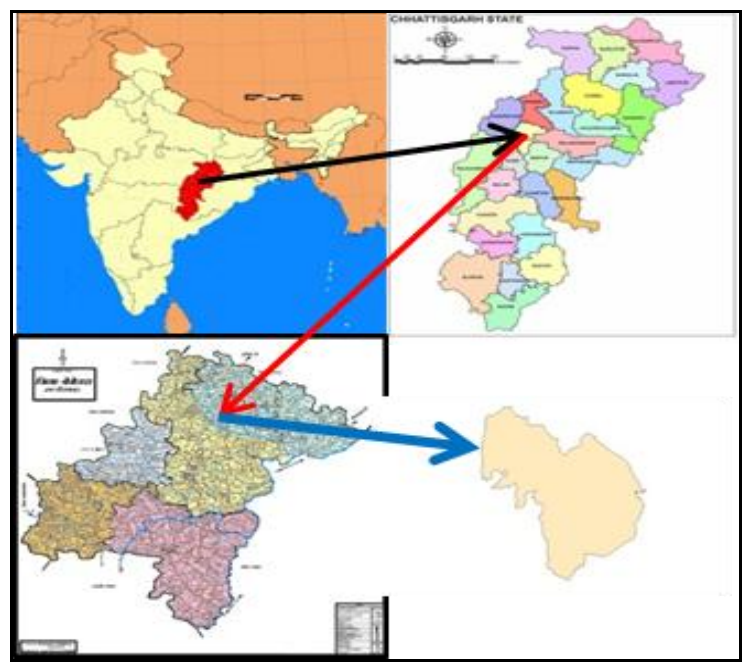

Fig.2 Layout showing the methodology of the study

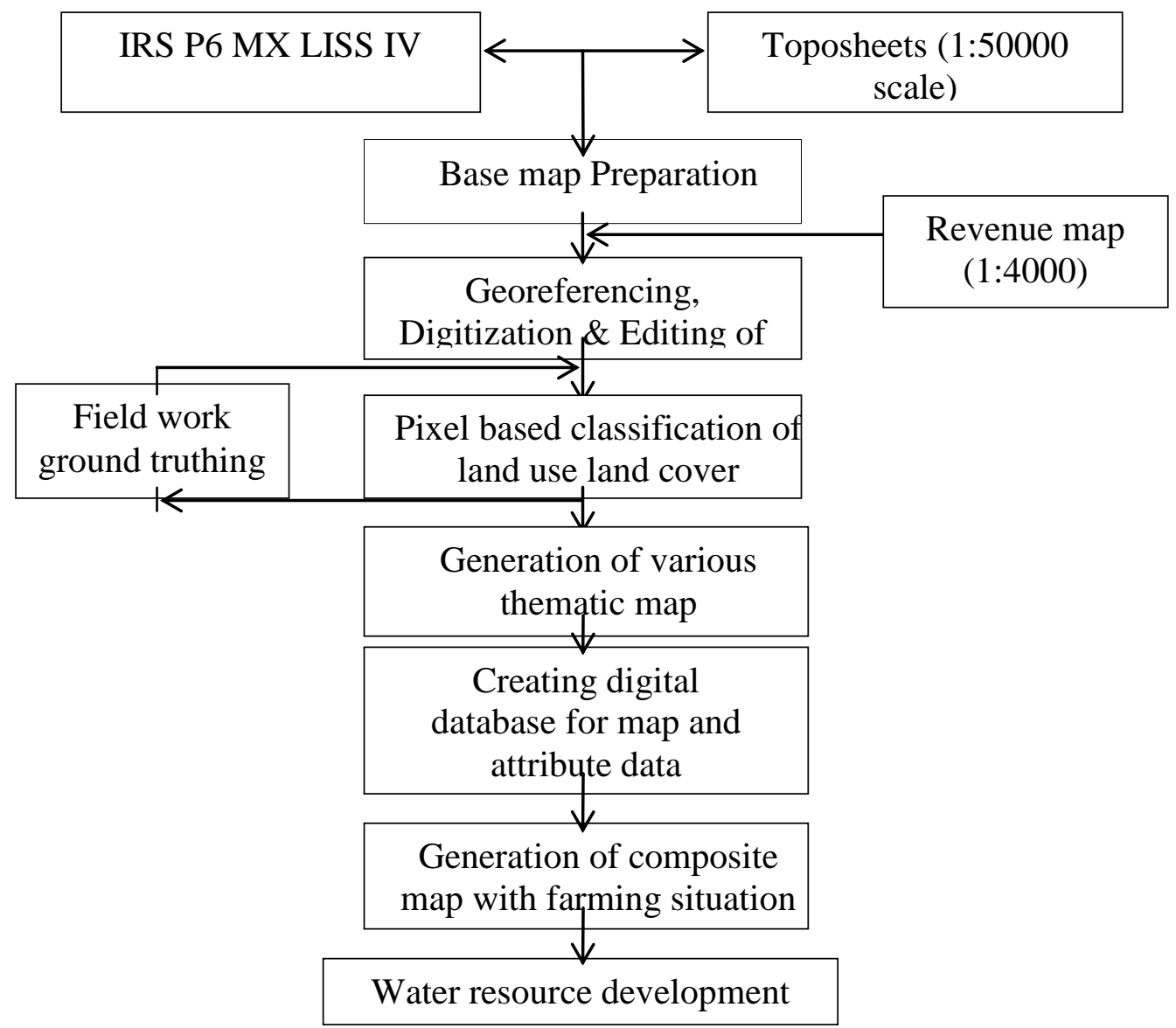


Fig.3\&4 Drainage map of the study area and land use classification of the study

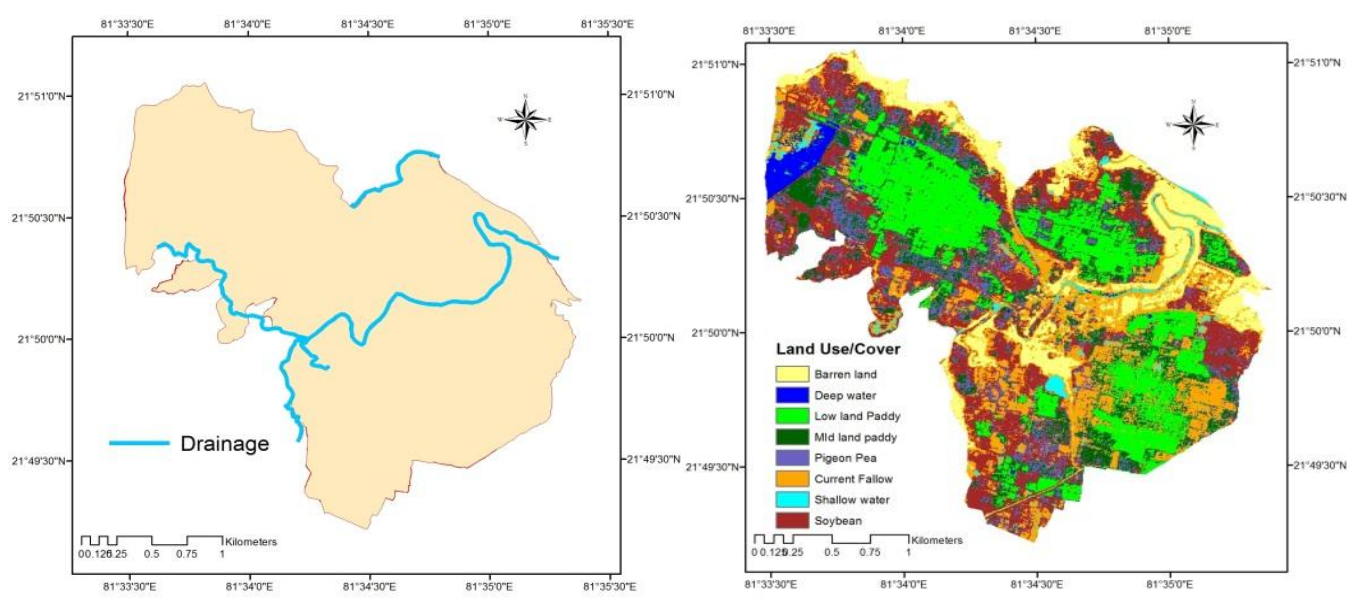

Fig.5\&6 Soil texture map of study area and digital elevation model of study area

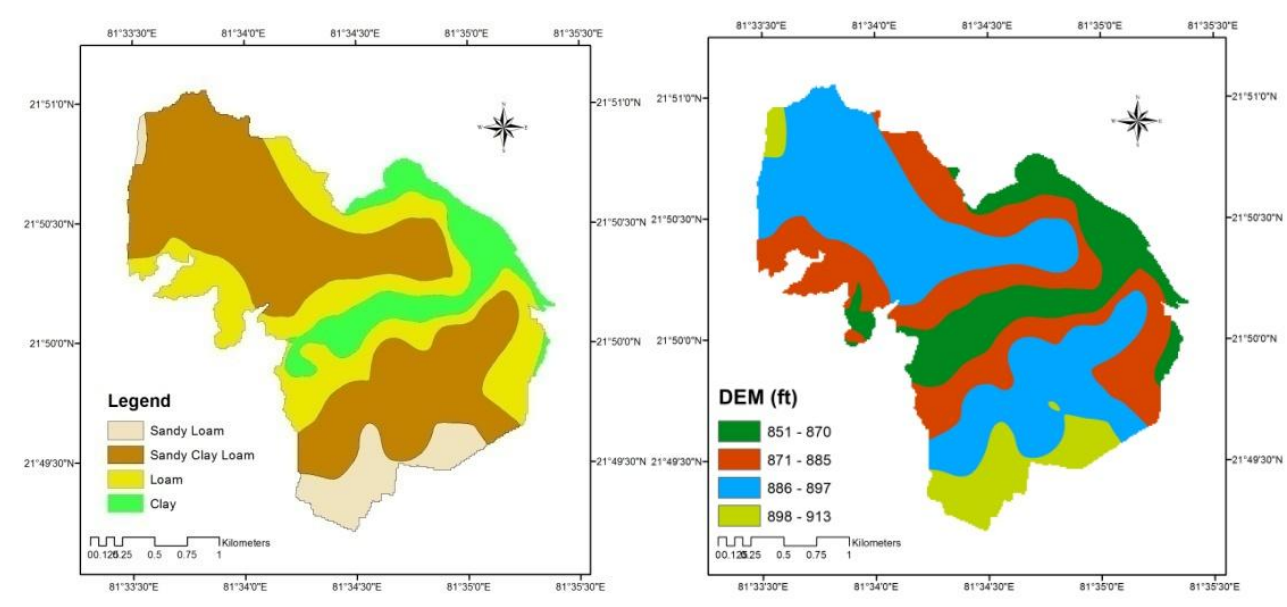

Fig.7 Water resource plan

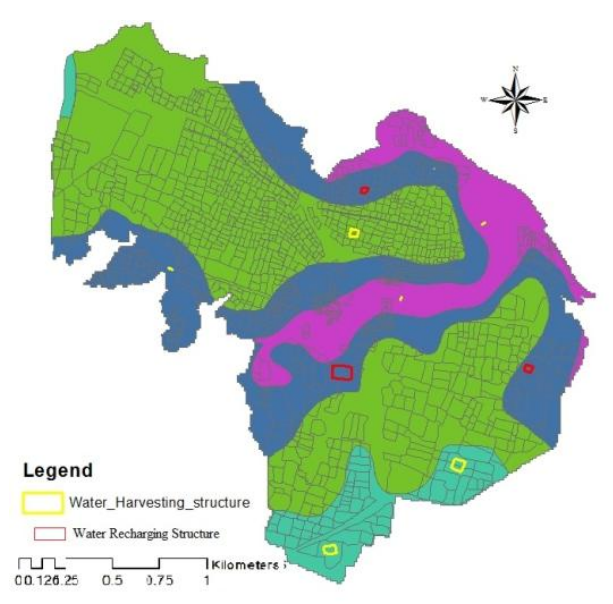


Different engineering structures are proposed for the water resource development and are depicted in Figure 7. The planning for water resource reflects the approach for the use of the resources in a careful manner for sustainable development of the micro watershed.

The present water availability in the micro watershed is presented in Table 1.

Conservation, management and development of water resources form integral component of the development plan. As per the proposed land use plan, 112 ha of current fallow under different farming situations can be brought to cultivation with the available water resources as presented in Table 2.

Suitable structures are suggested for surface water harvesting and ground water recharge. Proposing different soil and water harvesting structures plays a very crucial role, which requires a well-qualified and well-experienced work force with thorough knowledge in various water conservation programmes. For this purpose the following thematic layers like slope, flow direction and flow accumulation output raster maps along with drainage, land use/land cover, hydro geomorphology are used. The water resources management plan was generated to make the judicious and effective use of water resources of the watershed to enhance the productivity and mitigate drought. The plan indicates the sites for surface water development and sites for groundwater exploitation. Percolation tank were proposed on the upland situations (Bhata and Matasi farming situations) with emphasis on those area with high tube well density supported by slope map. The percolation tank will help in recharge of the ground water table and will support the farmers with ground water exploration using tube wells. Check dam and Farm ponds were proposed based on the slope and land use/ cover condition to provide additional water resources for the cropped land to be brought under cultivation. Different structures proposed for the water resource development are given in Table 3 and in Figure 7.
In conclusion, as per different soil health status, DEM, and drainage network different variety of crops as well as different water harvesting structure viz. Percolation tank (3 nos), Check dam (3 nos), and Farm ponds (3 nos) are proposed/suggested at appropriate locations, and water management plan was developed at field level specifying the use of all the revenue field based on the availability of natural resources and its potential.

Cadastral level land and water resource development plan was generated using geospatial techniques which enable us to accesses large volume of information for analysis to develop plan and implement appropriate package of practices as per the potential of the fields. The attribute of the developed geodatabase enable us to search any field by its cadastral/revenue as khasra number or by its owner's name. This user friendly and handy tool of information will definitely help in increase of the adoption of scientific planning by the farmers and the developmental agencies.

\section{References}

Gao, Z., Gao, W. and Chang, N.B. 2010. Impact of climate change and land use/land cover changes on the carbon cycle in china 1981-2000: A system based assessment. Biogeosci. Discuss., 7:5517-5555.

Hiese, N., Mich, N., Yanthan, M., Yeptho, H., Moatoshi, Lotha, R., Pienyü, K., Suokhrie, S., Murry, B. and Mor, S. 2011. Application of Geoinformatics in Land Resource Management at MicroWatershed level for sustainable development of Sanis, Wokha District, Nagaland. Dimension and direction of geospatial industry. Geospatial world forum 18-21, January Hyderabad.

Khalkho, D., Patil, S.K., Patel, S., G.P., Pali, 2013. Cadastral level Mapping for Efficient Natural Resources Management of Turenar cluster villages using Remote Sensing and GIS Technologies. J. Agric. Issues 18(1\&2), 55-60.

Kumar, B., Kumar, U. 2011. Micro watershed 
characterization and prioritization using Geomatics technology for natural resources Management international J. of geomatics and geosciences 1(4): 789-802.

Manchanda, M.L., Kudrat, M., Tiwari, A.K., 2002.Soil survey and mapping using remote sensing. Tropical Ecology 43, 6174.

Mangrule, V. N. and Kahalekar U. J., (2013) Watershed Planning and Development Plan by Using Rs and GIS of Khultabad Taluka of Aurangabad District. International Journal of Information and Computation Technology. 3(10): 10931100.

Patil, G.B., Nargaraju, M.S.S., Prasad, J., Shrivastava, R., 2010. Characterization, evaluation and mapping of landresources in Lendi watershed, Chadrapur district of Maharastra using Remote Sensing and GIS. Journal of Indian Society of Soil Science 58, 442-448.

Patil, S.S., Nargaraju, M.S.S., Prasad, J., Shrivastava, R., 2010. Characterization and evaluation of land resources of basaltic terrain for watershed management using remote sensing and GIS. Indian Journal of Soil Conservation 38, 16-23.

Praveen, G.S., Babu, B. M., Sarangamath, S. B. and Balakrishnan, P. 2013. Action plan for efficient land and water use in a miniwatershed near Mysore using remote sensing and GIS. International Journal of Agricultural Engineering, 6(2): 514-518.

Rout, J. and Ojha, A. 2012. Microwatershed management using RS and GIS technologies. Published in Geospatial world, March 2012.

Raghvendran, S. 2002. Cadastral mapping and land information system, Geospatial application paper.

S. P. Wani, P. Pathak, H.M. Tam, A. Ramakrishna, P. Singh and T. K. Sreedevi, 2002 "Integrated watershed management for minimizing land degradation and sustaining productivity in Asia", Proceeding of a Joint UNUCAS International Workshop, 8-13 September 2001, Beijing, China, 2002.

Shukla, A.E., Prasad, J., Nargaraju, M.S.S., Shrivastava, R., Kauraw, D.L., 2009. Use of remote sensing in characterization and management of Dhamni micro watershed of Chandrapur district of Maharastra. Journal of the Indian Society of Remote Sensing 37, 129-137.

Shrivastava, R., Saxena, R.K., 2004. Technique of large scale soil mapping using satellite remote sensing. International Journal of Remote Sensing 25, 679-688.

Velmurugan, V., Carlos, G.G., 2009.Soil resource assessment and mapping using remote sensing and GIS. Journal of the Indian Society of Remote Sensing 37, 511-525.

\section{How to cite this article:}

Madhukar Patel and Dhiraj Khalkho. 2019. Water Resource Management Plan of a MicroWatershed using Geospatial Techniques. Int.J.Curr.Microbiol.App.Sci. 8(02): 270-277. doi: https://doi.org/10.20546/ijcmas.2019.802.032 